\title{
Empirical study of professional priorities of the future preschool teacher
}

\author{
Yu. O. Volynets, N. V. Stadnik, T. L. Panchenko \\ Borys Hrinchenko University of Kyiv, Kyiv, Ukraine \\ Kyiv regional council municipal educational institution \\ Bila Tserkva Humanitarian and Pedagogical College, Bila Tserkva, Ukraine; \\ Corresponding author. Email: n.stadnik72@ukr.net
}

Paper received 05.02.21; Accepted for publication 22.02.21.

\section{https://doi.org/10.31174/SEND-PP2021-247IX98-10}

\begin{abstract}
A comprehensive scientific analysis of the problem of the motivation of the professional development of preschool teachers as a tool for improving the quality of preschool education was done. The results of an empirical study of the professional priorities of the future preschool teacher are presented. It was concluded that the formation of motivation for the professional development of preschool teachers is a complex process that depends on many components of activity at all stages of its implementation. The professional priorities of students - future preschool teachers, which will contribute to the formation of their professional selfdevelopment, their awareness of the importance of their own professional activities, and the value of building a professional career.

Keywords: professional priorities, professional training of future preschool teachers, motivation, quality of preschool education, professional development, continuing education.
\end{abstract}

Introduction. The problem of motivating the professional development of preschool teachers as a means of improving the quality of preschool education is at the center of the attention of many scientists, researchers, and practitioners. The quality of preschool education determines what awaits our country in the future. The desire of the Government of Ukraine to ensure high-quality preschool education declared in the Laws of Ukraine and state documents («On Education», «On Higher Education», «On Preschool Education», «On Child Protection», the National Doctrine of Education in Ukraine in the XXI century, a Basic component of preschool education in Ukraine, the UN International Convention on the Rights of the Child, the National Strategy for Educational Development in Ukraine until 2021, and other regulations on childhood), necessitates reform of all areas of education management, namely the system of professional training, in particular - study and the introduction of modern, progressive foreign experience. The most successful in the labor market will be those preschool professionals who are motivated by the chosen profession, able to learn throughout life, think critically, work in a team, communicate, put forward ideas and set goals, and achieve them. That is why the chosen topic of our study is relevant today and requires finding ways to improve the quality assurance system of higher pedagogical education.

A brief overview of publications on the topic. In pedagogical theory, the essence of understanding the definition of the concept «professionalism», «professional training of a teacher», professional activity is quite thoroughly revealed and its structure is characterized. The professional activity has become the subject of research by psychologists and teachers, namely: V. Andrushchenko, G. Belenka, V. Bespalko, P. Blonsky, K. Volynets, Y. Volynets, N. Kuzmina, N. Kukharev, L. Makridina, S. Martynenko, N. Nychkalo, O.Savchenko, S. Sysoeva, L. Spirina, V. Slastyonina, L. Khomych, L. Khoruzha and other leading scientists. Scientists have developed the theoretical and practical foundations of professional training as a condition for the personal and professional development of teachers (I. Zyazyun, N. Kichuk, N. Kuzmina, S. Sysoeva, O.Shcherbakova, etc.); the conditions and possibilities of professional formation are studied (V. Aseev, G.Ball, I. Bekh, V. Bobrova, I. Bogdanova, J.
Vasilkevich, K. Durai-Novakova, S. Yelkanova, L. Levina, N. Levinets, A. Linenko, and others). The problem of training future teachers has also been studied in the works of O. Abdullina, B. Andrievsky, G. Klovak, M. Knyazyan, L. Kondrashova, O. Pekhota, M. Falko, etc.; in particular, O. Artemov, G. Belenko, O. Boginich, A. Bogush, O. Vashak, L. Wenger, N. Golota, I. Yerofeeva, M. Mashkina, M. Mashovets, N. Stadnik considered the issues of training of educators.

The purpose of the article is to analyze the results of an empirical study of the professional priorities of the future preschool teacher.

Materials and methods. The following methods were used in the research process: analysis, comparison, classification, generalization, systematization, which were used to determine the professional priorities of the preschool teacher.

Presenting main material. In higher education institutions, more and more attention is paid to the quality of education, self-development, self-organization, analytical, flexibility and independence of thinking, responsibility, etc. Modern society needs a teacher-innovator, a teacherresearcher who has creative abilities, information and communication technologies, creativity, has a high level of intellectual development. That is why one of the factors ensuring the country's competitiveness at the global level is to improve the quality of training of preschool education specialists, the formation of positive motivation in them for the future profession of preschool education specialists. Modern preschool institutions place high demands on the organization of educational activities of the younger generation, which is why they need competent educators who would have developed research, analytical, communicative, cognitive, informational, organizational, constructive skills that are implemented in general (civic, social, cultural), leadership, entrepreneurial) and professional competencies (linguistic-communicative, methodical, information-digital, psychological, emotional-ethical, competence of pedagogical partnership, inclusive, healthpreserving, design, prognostic, organizational, evaluativeanalytical, innovative, reflective).

We note that understanding the concept of «professionalism» means using their professional and pedagogical skills in activities, a good understanding of general 
trends in the educational process, its place, direction, the effectiveness of the child's activity, and the ability to design a developing pedagogical environment and himself.

In our view, the concept of «teacher training» refers to the profession as a kind of employment, and «professional training of future educators PEI» - a type of employment. These concepts are correlated as general and special, as categories of the genus (professional training) and species (professional training). Professional training of a teacher presupposes the acquisition of knowledge and abilities in psychological and pedagogical disciplines, while professional training of future educators of PEI - acquisition of knowledge and abilities in professional methods.

However, a more thorough study of philosophical, psychological, pedagogical, and methodological literature allows us to conclude that, despite a large number of studies on the problems of professional training of future preschool teachers in higher education, the issue of motivating professional development of preschool teachers as a means of improving preschool education. conditions of European integration have not yet received due attention.

In this regard, E. Kulyk, in particular, notes that the education system should ensure the development of the younger generation, be open to real innovations, critical perception of neoplasm, and at the same time should shape the personality. Everyone is constantly striving to improve, perfect and develop the conditions of their work and life in general. To instill the desire for innovation, to develop the individual's ability to create, education itself must be in an atmosphere of creativity. The introduction of innovations involves increasing the productivity of educational activities and the more effective involvement of students in creative work. Education is required not only to master but also to create a new and through it the education of creative personality, that is, innovative activities should become part of the educational process. The teacher has a leading role in the introduction of innovations in education and training, the inner desire of the teacher to change must change $[7,91]$.

In our opinion, one of the main elements of motivation for professional development is the stimulation of work and self-development. At the center should be a person with his interests, as a free person who is aware of his responsibility to himself, society, children. According to the study, most teachers are motivated to succeed in professional activities - financial motivation, recognition in the team, professional development, self-realization, providing the technical base, and partnership in the team. Note that important in the training of students - future preschool teachers is pedagogical practice, which is an important component of professional training, aimed at consolidating and implementing in a specially created environment acquired by students psychological, pedagogical, methodological, and research skills necessary for future professional development. activities in PEI. It is a means of creative development and self-development of future preschool teachers; formation of professionally significant qualities in them; the possibility of using the results of research activities in the process of pedagogical practice and readiness for innovative pedagogical activities; increasing the psychological and pedagogical competence of the future educator of preschool education insti- tutions. Particular attention needs to be paid to ensuring the continuity and continuity of pedagogical practice. The program of the Kyiv University named after Borys Hrinchenko and the Municipal Institution of the Kyiv Regional Council «Bila Tserkva Humanitarian and Pedagogical Professional College» identifies various types of continuous pedagogical practice, which include observation of students in the educational process of PEI. The pedagogical practice is a mandatory type of bachelor's educational work, which involves solving several tasks of professional training, improving the quality of the educational process in the PEI.

The ascertaining stage of the experiment was aimed at the formation of the motivational component of future preschool teachers to professional activity. The sample of participants in the observational experiment was 136 fulltime respondents. They were students of the Pedagogical Institute of the Borys Hrinchenko University of Kyiv and the Communal Institution of the Kyiv Regional Council «Bila Tserkva Humanitarian and Pedagogical Professional College».

The purpose of the study is to determine the professional priorities in the pedagogical activities of future preschool teachers. Thus, in the process of the survey, it was found that a significant number of respondents (129 people, 94,9\%) share the opinion that the profession of educator requires a person of deep dedication, great patience, and boundless love for their work; 2 people $(1,5 \%)$ do not share this opinion and 5 people $(3,7 \%)$ did not even think about this topic. The purpose of studying in a higher education institution, respondents believe is not the simple acquisition of knowledge and the development of creative abilities.

To the question «Do you plan to work in preschool institutions after graduation? - 45,6\% (62 students) answered that they plan; 37,5\% (51 students) - answered that it is difficult for them to give an answer and 16,9\% (23 students) - do not plan to work in the specialty. But only 46,3\% (63 students) are psychologically ready to work in PEI, the rest are not quite ready 53,3\% (73 people).

The results of the survey allowed us to find out what difficulties future preschool teachers are afraid to face in the school. Thus, $22,8 \%$ (31 people) called the difficulties of communication in the teaching staff; $65,4 \%$ (89 people) establishing partnerships with parents; 32,4\% (44 people) organization of educational activities with children; 47,8\% (65 people) conducting open forms of activity in PEI; $64 \%$ (87 people) lack of practical experience; $22,1 \%$ (30 people) possession of professional competencies.

We found out what is the most fascinating students are future preschool teachers in their profession of PEI educator. $44,9 \%$ (61 people) answered that it is an opportunity to realize their abilities; $66,9 \%$ (91 people) - opportunity to communicate with children; $85,3 \%$ (116 people) opportunity to help children grow up to be decent, kind, honest people; 70,6\% (96 people) - the opportunity to pass on their knowledge and skills to children and $25,7 \%$ (35 people) - the opportunity to feel respected.

In Table 1 we present the results of the survey of respondents «What personality traits do preschool teachers need for successful professional activity?». 
Table 1. Personality qualities of a preschool teacher for successful professional activity, in $\%$

\begin{tabular}{|l|c|c|}
\hline \multicolumn{1}{|c|}{ Personality qualities } & $\begin{array}{c}\text { respondents } \\
\text { (number) }\end{array}$ & $\mathbf{y} \%$ \\
\hline professionalism & 107 & 78,7 \\
\hline responsibility & 130 & 95,6 \\
\hline communication & 119 & 87,5 \\
\hline kindness & 117 & 86 \\
\hline patience & 124 & 91,2 \\
\hline love to children & 123 & 90,4 \\
\hline artistry & 71 & 52,2 \\
\hline purposefulness & 89 & 65,4 \\
\hline interest in their profession & 103 & 75,7 \\
\hline creativity & 124 & 91,2 \\
\hline spirituality & 72 & 52,9 \\
\hline stress resistance & 113 & 83,1 \\
\hline pedagogical tact & 101 & 74,3 \\
\hline modesty & 43 & 31,6 \\
\hline attentiveness & 122 & 89,7 \\
\hline high moral culture & 89 & 65,4 \\
\hline general erudition & 73 & 53,7 \\
\hline tolerance and perseverance & 106 & 77,9 \\
\hline observation & 113 & 83,1 \\
\hline objective self-esteem & 86 & 63,2 \\
\hline interest in pedagogical activity & 103 & 75,7 \\
\hline culture and expressiveness of speech & 106 & 77,9 \\
\hline efficiency & 86 & 63,2 \\
\hline sense of humor & 77 & 56,6 \\
\hline organization & 115 & 84,6 \\
\hline other: & 6 & 4,4 \\
\hline mobility & 1 & 0,7 \\
\hline desire to work & 1 & 0,7 \\
\hline empathyness & & 0,7 \\
\hline
\end{tabular}

According to the results of the survey, the qualities that are necessary for a preschool teacher for successful professional activity are responsibility $(95,6 \%$ of respondents), patience $(91,2 \%$ of respondents), creativity $(91,1 \%$ of respondents), and love for children $(90,4 \%$ of respondents).

The results of empirical research suggest that there is a contradiction between students' understanding of the need for professional skills and their low level of formation. Let's find out, what skills, in the opinion of the student the future preschool teacher, should have a teacher of PEI? According to the results of the survey, the respondents consider the following skills necessary: organizational - $132(97,1 \%)$; communicative -127 people $(93,4 \%)$, cognitive -118 people $(86,8 \%)$ and didactic -118 people $(86,8 \%)$; information - $110(80,9 \%)$; pedagogical equipment - 104 people $(76,5 \%)$; research - $103(75,7 \%)$; constructive - 85 (62,5\%); applied - $81(59,6 \%)$; analytical $-75(55,1 \%)$; suggestive - $48(35,3 \%)$; perceptual 55 (40,4\%) (look Fig. 1).

The analysis of psychological and pedagogical sources on the researched problem allowed us to conclude that actually research activity is the basic source of professional self-development of the educator. In the process of educational activity, teachers of higher education institutions should create conditions that would form the creative activity of students and the desire for research.

External stimuli in the educational process are also the educational environment (the content of educational material, organizational forms, methods and means of teach- ing, communication, professional competence, and pedagogical skills of the teacher, psychological microclimate in the team), encouragement (rating assessment of students' knowledge; credit or exam based on current results; participation in competitions, Olympiads, conferences; study according to an individual plan with permission to attend classes; recommendation for master's, graduate school; nominal scholarships, awards; transfer of contract students to vacant places in the state order). It is proved that internal stimuli are usually associated with the needs, motives, interests, desires, and needs of the individual to realize their abilities [8, 192].

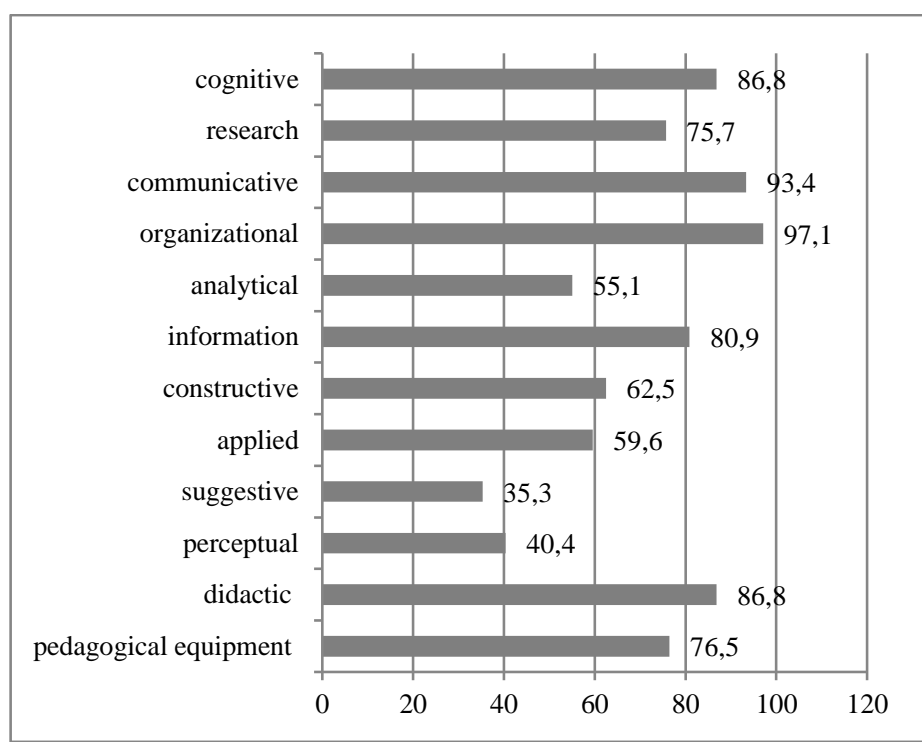

Fig. 1. Skills identified in the process of empirical research of professional priorities of the future preschool teacher (in \%)

To the question «What would you like to change in modern preschool education? Your suggestions for improving the content of preschool education» received mixed and varied responses. Most students believe that we should move away from the old methods and techniques of working with children and replace them with new, modern forms of educational activities. For the older - experienced generation, preschool education specialists listened to young specialists who offer innovations, interesting ideas, and projects, own ICT. Also among the answers were suggestions for pedagogical practice - to increase it to have time to perform interesting forms of work with children and reduce the writing of reports and documents. Some respondents answered that everything suits them and nothing needs to be changed, but when there are a large number of children in groups, it is more difficult to organize them. They offered to pay attention to the attitude of children, to pay more attention to their moral and physical problems. An interesting idea was «to add trips to museums, cinemas (for sessions that will be useful for children's development), circuses (which do not use animals in their performances), open zoos, theaters (with a program for children), or nature trips with parents». It should be noted that future specialists in preschool education understand the importance of the partnership between children and parents, said in their answers proposals «to spread as much as a possible partnership with parents and staff, to involve parents in organizing the educational process of children». The most painful 
issues remain «the availability and financial support of the state of educators PEI, modernization of pedagogical interaction between participants in the educational process, the technical base of PEI, equipment, and resources».

Thus, as a result of scientific research, we can say that the choice of professional priorities of future preschool teachers is influenced by the formation of their professional self-development, their awareness of the importance of their own professional activities, and the value of building a professional career. The task of a preschool teacher is to convince and encourage them to form their own system of professional priorities.

Conclusions and prospects. Thus, the analysis of the process of the formation of professional priorities and motivation of the professional development of a preschool teacher involves the definition of academic disciplines that are directly aimed at preparing students for professional work with preschool children. Students' studying activities should be the basis for developing the content and technology of these activities and should take into account the level of their creative abilities, academic achievements, interests, activities, etc. We note that the formation of motivation for the professional development of preschool teachers is a complex process that depends on many components of activity at all stages of its implementation, the main of which are the motives that determine the effective work and personality of the future preschool teacher. A new style of living standard is coming «Education for all, we learn all our life!». And only by studying in the conditions of continuous education, we will be able to reach a high level of professional competence, self-development. Having an active position in our own lives and having pedagogical skills, we will provide quality preschool education.

We can see prospects for further research in the selection and development of diagnostic tools to determine the formation of professional priorities of future preschool teachers, development of information and methodological materials for implementing a model of professional selfdevelopment of future preschool teachers in the educational environment of higher education.

\section{REFERENCES}

1. Volynets, Yu. O., Stadnik, N. V. Introduction of information technologies in the process of professional training of future preschool teachers. Narodna osvita. Electronic scientific professional publication, 2020. 2-nd ed. (41). URL: https://cutt.ly/ckkDniY.

2. Volynets, Yu. O., Volynets, K. I. Formation of professional abilities of future preschool teachers in the conditions of European integration. Educational discourse. Electronic scientific professional publication, 2020. 3-rd ed. (39). URL: https://cutt.ly/ekkDIbs.

3. Volynets, Yu. O., Stadnik, N. V., Volynets, K. I. Formation of future specialists' readiness for preschool education in carrying out professional activity in the conditions of European integration. Innovative scientific researches: European development trends and regional aspect. 1-st ed. Riga, Latvia :

«Baltija

Publishing», https://cutt.ly/qkkDFDM.

4. Law of Ukraine «On Higher Education» dated 09.08.2019 № 1556-VII. URL: https://cutt.ly/fkkDpkV.

5. Law of Ukraine «On Preschool Education» dated 11.07.2001 № 2628-III. URL: https://cutt.ly/GkkDgxf.

6. Law of Ukraine «On Education» dated 05.09.2017 № 2145VIII. URL: https://cutt.ly/CkkD5FH.

7. Kulik E. V. Preparation of future teachers for research activities: monograph. Kyiv; Drogobich: Kolo, 2004. 382 p.

8. Chernihivska, N.S. Preparation of the future teacher of a foreign language for self-educational activity: dis. ... Cand. ped. Science: special. 13.00.04 «Theory and methods of vocational education». Kyiv, 2011. 192 p.

\section{ЛІТЕРАТУРА}

1. Волинець, Ю. О., Стаднік, Н. В. Упровадження інформаційних технологій у процесі професійної підготовки майбутніх дошкільних педагогів. Народна освіта. Електронне наукове фахове видання, 2020. Вип. 2 (41). URL: https://cutt.ly/ckkDniY.

2. Волинець, Ю. О., Волинець, К. І. Формування професійних здібностей майбутніх дошкільних педагогів в умовах євроінтеграції. Освітологічний дискурс. Електронне наукове фахове видання, 2020. Вип. 3 (39). URL: https://cutt.ly/ekkDIbs.

3. Volynets, Yu. O., Stadnik, N. V., Volynets, K. I. Formation of future specialists' readiness for preschool education in carrying out professional activity in the conditions of european integration. Innovative scientific researches: European development trends and regional aspect. 1st ed.
Riga, Latvia : «Baltija Publishing», 2020. P. 38-55.URL: https://cutt.ly/qkkDFDM.

4. Закон України «Про вищу освіту» від 09.08.2019 № 1556-VII. URL: https://cutt.ly/fkkDpkV.

5. Закон України «Про дошкільну освіту» від 11.07.2001 № 2628-

6. Закон України «Про освіту» від 05.09.2017 № 2145-VIII. URL: https://cutt.ly/CkkD5FH.

7. Кулик Є.В. Підготовка майбутніх вчителів до дослідницької діяльності : монографія. Київ; Дрогобич : Коло, 2004. 382c.

8. Чернігівська, Н. С. Підготовка майбутнього вчителя іноземної мови до самоосвітньої діяльності: дис. ... канд. пед. наук: спец. 13.00.04 «Теорія і методика професійної освіти». Київ, 2011. 192 с. III. URL: https://cutt.ly/GkkDgxf. 